\title{
Respons Ulama Aceh Terhadap Al-Qur'an Al-Karim dan Terjemahan Bebas Bersajak dalam Bahasa Aceh
}

\author{
Munawir Umar, Yusuf Rahman \\ UIN Syarif Hidayatullah, Jakarta \\ Corresponding E-mail: munawirumar93@gmail.com
}

\begin{abstract}
This paper analyzes the responses of the Acehnese Ulama to the Al-Qur'an Al-Karim and the Poetic Free Translation in the Aceh language written by Teungku Mahjiddin Jusuf. The methodology used is descriptive-analytical qualitative to describe the response of the Acehnese Ulama using the hermeneutic, anthropological and literary approaches. This study found a variety of responses from Acehnese ulama by concluding as follows. First, from the aspect of sound equality and rhythm, the scholars have given some notes that the translator should pay attention and look for other suitable equivalent words so that they do not affect the distortion of the meaning of the Qur'anic content. Second, in the aspect of fawātih al-Suwār (hurf muqațta'ah) and the mutasyabihat verse, the scholars agreed with the translation approach used because it was in accordance with the studies of previous scholars with various existing literatures.
\end{abstract}

Keywords: Translating the Verse of the Quran, Ulama's Response, Poetry.

\begin{abstract}
Abstrak: Paper ini menganalisis respons Ulama Aceh terhadap Al-Qur'an Al-Karim dan Terjemahan Bebas Bersajak dalam Bahasa Aceh yang ditulis oleh Teungku Mahjiddin Jusuf. Metodologi yang digunakan adalah kualitatif deskriptif-analitis untuk mendeskripsikan respons Ulama Aceh dengan menggunakan pendekatan hermeneutika, antropologi, dan sastra. Kajian ini menemukan ragam macam respons ulama Aceh dengan menyimpulkan sebagai berikut. Pertama, dari aspek persamaan bunyi dan irama, para ulama memberikan beberapa catatan bahwa hendaknya penerjemah memperhatikan dan mencari padanan kata lain yang sesuai sehingga tidak berimbas pada distorsi makna kandungan Alquran. Kedua, pada aspek fawātih al-Suwār (hurf muqațta'ah) dan ayat mutasyabihat, para ulama setuju dengan pendekaran terjemahan yang digunakan karena sudah sesuai dengan kajian-kajian para ulama terdahulu dengan berbagai literatur yang ada.
\end{abstract}

Kata Kunci: Terjemah Al-Quran Bersajak, Respon Ulama, Puitisasi. 


\section{Pendahuluan}

Ketinggian bahasa Alquran dari sudut pandang balaghah telah banyak membuat perhatian banyak orang dari semenjak dahulu hingga sekarang. Bahkan pada masa awalnya turunnya Alquran, para pengingkarnya pun hendak menandingi bahasa Alquran dan ternyata hal tersebut pun tidak mampu mereka lakukan. Begitu pula dalam relasinya dengan hari ini, para orientalis terus mengkaji Alquran dengan berbagai motifnya, ada di antara mereka yang secara jujur ingin membuktikan kebenaran Alquran dan ada pula di antara mereka yang ingin mencari titik lemah dari Alquran dengan berbagai pendekatan mereka. Karena itu, Alquran perlu diinterpretasikan dalam berbagai bahasa dunia agar maksud Alquran bisa tersampaikan baik secara umum maupun secara terperinci. Karena Alquran ditulis dalam bahasa Arab dengan ketinggian bahasanya, maka Alquran perlu diterjemahkan kepada bahasa lain. ${ }^{1}$

Adapun pada sisi lain, penerjemahan Alquran bukanlah sebuah pekerjaan yang mudah dilakukan, membutuhkan kepada penguasaan detail terhadap bahasa Arab dan bahasa sasaran yang hendak diterjemahkan. Meskipun pada realitasnya bahwa terjemahan tidaklah dapat mewakili secara keseluruhan terhadap maksud yang diinginkan oleh Alquran. Pernyataan ini diperkuat oleh gagasan yang ditulis Muchlis M. Hanafi dalam artikel "Problematika Penerjemahan Alquran" bahwa sungguh sangat sulit dalam rangka menjadi seorang penerjemah bahkan ia memiliki tanggung jawab moral yang begitu besar dalam rangka menjaga otentitas dan orisinalitas teks asal, terlebih yang hendak diterjemahkan adalah Alquran firman Allah Swt. Tidak sedikit ditemukan bahwa penerjemah sering kali melakukan kesalahan dan kekeliruan dalam penerjemahan sebuah teks. Sering pula ditemukan missing terhadap teks dasar jika seorang penerjemah tidak mengetahui maksud dari teks tersebut. ${ }^{2}$ Oleh sebab itu, menjadi seorang penerjemah Alquran membutuhkan pada kejujuran agar mampu tersampaikan maksud Alquran disamping penguasaan ilmu-ilmu pendukung dalam rangka penerjemahan tersebut.

Fenomena tersebut pada gilirannya memunculkan spekulasi di lingkar para ulama tafsir bahwa menerjemahkan Alquran tanpa melibatkan unsur kehati-hatian akan

\footnotetext{
${ }^{1}$ Muchlis M. Hanafi, 'Problematika Terjemahan Al-Qur'an Studi pada Beberapa Penerbitan AlQur'an dan Kasus Kontemporer”, Jurnal Suhuf, Vol. 4, No. 2, 2011, 169.

${ }^{2}$ Muchlis M. Hanafi, "Problematika Terjemahan Al-Qur'an Studi pada Beberapa Penerbitan AlQur’an dan Kasus Kontemporer”, Jurnal Suhuf, Vol. 4, No. 2, 2011, 169.
} 
berakibat pada sisi teologis karena telah mengintervensi Alquran sebagai kalam Allah Swt sekaligus menjadi mukjizat atas keberadaan Nabi Muhammad Saw sebagai Rasul terakhir sepanjang masa. Di antara spekulasi itu, ada pula para ulama yang menolak menerjemahkan Alquran secara totalitas, karena menurut mereka Alquran sebuah objek yang untranslateable atau sama sekali tidak dapat diterjemahkan. Bermula dari aspek itu lah maka para ulama merumuskan dua metode penerjemahan Alquran, yaitu terjemah dengan metode literlek (tarjamah al-lafzhiyah) dan terjemah dengan metode non-literlek (tarjamah al-Tafsiriyah). ${ }^{3}$ Lebih detail lagi, Mannā' al-Qaț̣an menambah sebuah metode yang menurutnya urgen untuk dijadikan sebagai metode penerjemahan Alquran, yaitu tarjamah al-Maknawi. ${ }^{4}$

Jika melihat dalam konteks ke-Indonesian, maka pro kontra terkait mungkin atau tidaknya menerjemahkan Alquran juga muncul di kalangan para pakar semenjak mula adanya kitab Tarjumān Al-Mustafid karya 'Abd al-Ra'uf Al-Singkili. Hingga pada kurun akhir abad ke 20 hal tersebut juga memunculkan dilema dengan munculnya penerjemahan Alquran Berwajah Puisi yang ditulis oleh HB. Jassin dengan segala penolakannya. Namun berbeda lagi dengan karya Teungku Mahjiddin Jusuf berjudul AlQur'an Al-Karim dan Terjemahan Bebas Bersajak dalam Bahasa Aceh yang justru mendapatkan apresiasi dari berbagai kalangan yang ada, bahkan termasuk dari Menteri Agama.

Paper ini membahas respon ulama Aceh terhadap penerjemahan puitis Alquran, yaitu Al-Qur'an Al-Karim dan Terjemahan Bebas Bersajak dalam Bahasa Aceh yang ditulis oleh Teungku Mahjiddin Jusuf. Sebelum membahas respon tersebut, paper ini diawali dengan pembahasan tentang kontroversi puitisasi terjemahan Alquran dan klasifikasi ulama Aceh.

\footnotetext{
${ }^{3}$ Bila dilihat secara lebih spesifik dari berbagai literatur maka akan ditemukan bahwa para ulama secara umum (jumhur) menolak model pertama dalam menerjemahkan Al-Qur'an karena alasan bahwa Al-Qur'an tidak dapat dialihbahasakan. Bagi mereka pula bahwa aspek ini akan mengandung reduksi dan distorsi pemahaman tertentu dan bahkan bisa berpotensi menghilangkan maksud utuh dari pada pemilik teks. Tetapi mereka justeru menerima model kedua, yaitu terjemah tafsiriyah, karena pada aspek ini AlQur'an tidak dijabarkan perkat, tetapi dijabarkan dengan pemahaman secara utuh tanpa terikat dengan kosa kata Al-Qur'an. Lihat. Ziauddin Sardar, 2011. Reading the Qur'an: The Contemporary Relevance of the Sacred Text of Islam. Cet. I, (New York: Oxford University Press, 2011), 40.

${ }^{4}$ Mannā' Khalil al-Qațān, Mabāhï̉ fì 'Ulūm Al-Qur'ān, Terj. Aunur Rafiq El-Mazni, Cet. XXII, (Jakarta: Pustaka Al-Kautsar, 2015), 396.
} 


\section{Wacana dan Kontroversi Puitisasi Terjemah Alquran}

Puitisasi Alquran pada awal perkembangannya di akhir tahun 1970 hingga 1980 telah menuai kontroversi di Indonesia bahkan hingga kecaman dari berbagai komunitas muslim yang pada saat itu dilakukan oleh HB. Jassin. Kematian Arsiti, istri Jassin, pada 12 Maret 1972 membangunkan kesadaran baru dalam diri HB. Jassin. Selama tujuh malam, di rumahnya, acara tahlilan digelar. Secara tidak sadar, ayat-ayat Alquran yang dibacakan setiap malam itu, mengusik hati Jassin dan menggiringnya untuk menerjemahkan teks-teks tersebut. Niatnya ini didorong suatu kesadaran bahwa Alquran sangatlah puitis, adalah sangat wajar bila terjemahannya juga dibuat secara puitis. Dan pada 7 Oktober 1972, ia memulai melaksanakan proses penerjemahan itu. Dua tahun ke mudian, tepatnya pada 18 Desember 1974, Jassin menyelesaikan terjemah seluruh ayat Alquran. Setelah edisi pertama terbit, Jassin diserang banyak pihak, karena dipandang dia tidak mempunyai ilmu yang dibutuhkan di dalam menerjemahkan Alquran. Oleh karena itu, demikian para pengkritiknya berargumen, Jassin tidak layak untuk menerjemahkan Alquran dan dengan demikian hasil terjemahannya itu juga tidak layak untuk dibaca. ${ }^{5}$

Jassin adalah berlatar belakang seorang kritikus sastra Indonesia yang namanya sangat tersohor dan terkenal. Karena keahliannya dalam bidang sastra, membuatkannya ingin menjelajah lebih jauh dengan menerjemahkan Alquran pada pendekatan sastra dengan judul Al-Qur'an berwajah Puisi dan kemudian diformulasikan secara lebih puitis lagi dalam Al-Qur'an Al-Karim Bacaan Mulia. Pada dasarnya, buah karya ini dilahirkan oleh Jassin tidaklah bermaksud untuk membuat sebuah tafsiran dan interpretasi baru terhadap makna dan kandungan Alquran, tetapi hanya sebagai sebuah pendekatan agar Alquran dengan gaya yang berbeda dengan tujuan bisa dipahami dan dihayati dengan sajian yang indah oleh pembaca. ${ }^{6}$ Lebih dari itu, model penulisannya pula dilakukan sebagaimana puisi dan dibaca pula dengan irama tertentu sebagaimana halnya puisi. Maka dalam hal ini secara otomatis akan terjadi potongan-potongan baik

${ }^{5}$ Edy A. Effendi, “Kontroversi di Sekitar HB. Jassin”, dalam Jurnal Ulumul Qur'an, November 1993. Lihat juga Islah Gusmian, "Kontroversi Mushaf Al-Qur'an Berwajah Puisi Karya HB. Jassin: Studi tentang Tatacara Penulisan dan Layout Mushaf Al-Qur'an”, dalam Jurnal al-Itqan, Vol. 1, No.1, Februari-Juli 2015, 47.

6 HB. Jassin, Al-Qur'an Al-Karim Bacaan Mulia, (Jakarta: Djambatan, 1991), cet. 3. Selengkapnya lihat Nazwar Syamsu, Koreksi Terjemah Al-Qur'an Al-Karim Bacaan Mulia HB. Jassin, (Padang Panjang: Pustaka Sa'adiyyah, 1978). Lihat juga Oemar Bakry, Polemik H. Oemar Bakry dengan H.B. Jassin tentang Al-Qur'an Al-Karim Bacaan Mulia, (Jakarta: Mutiara, 1979). Lihat juga Siradjuddin Abbas, Sorotan atas Terjemahan Al-Qur'an HB. Jassin, (Jakarta: Pustaka Tarbiyah, 1979). 
dari segi ayat Alquran atau pun arti yang disajikan. Karena sebab itu pula, maka karya yang ditulis oleh Jassin menjadikan kontroversi tersendiri di Indonesia.

Setidaknya ada tiga yang menyebabkan terjadinya kontroversi dan perdebatan terhadap Al-Qur'an Al-Karim Bacaan Mulia atau Al-Qur'an Berwajah Puisi karya HB. Jassin. Pertama, aspek kemapanan yang dimiliki oleh HB. Jassin dalam konteks penguasaannya terhadap khazanah ilmu keislaman, seperti ilmu bahasa Arab dengan segala cabangnya sebagai pisau bedah dalam menerjemahkan Alquran. Kedua, karya HB. Jassin menjadi sebuah karya yang telah mengada-ngada dalam perkara agama (bid'ah). Dalam satu sisi, HB. Jassin memang telah mampu membuat sebuah inovasi baru dalam kajian Alquran. Tetapi sebuah inovasi juga harus bertolak pada konsep keilmuan tanpa merusak kesakralan sebuah kitab suci yang notabenenya adalah firman Allah Swt. Ketiga, Alquran diturunkan dalam bahasa Arab, namun bukan berarti Alquran itu bisa diposisikan satu sejajar dengan teks-teks buku sastra bahasa Arab lainnya. Karena sudah begitu nyata bahwa Alquran semenjak dahulu kala membela dirinya sendiri bahwa ia bukan lah kitab sastra, namun ia adalah kitab yang jauh melebihi sastra yang tiada tanding. ${ }^{7}$

Mengutip pernyataan Islah Gusmian dalam artikel berjudul, "Kontroversi Mushaf Al-Qur'an Berwajah Puisi Karya HB. Jassin: Studi tentang Tatacara Penulisan dan Layout Mushaf Al-Qur'an" mengatakan bahwa perdebatan terkait bahwa Alquran itu berbentuk puitis atau proses memang sudah terjadi jauh sebelumnya. Dalam pandangan mayoritas ulama mengatakan bahwa Alquran sebagai kitab yang sangat agung pada dasarnya telah memiliki nilai-nilai puisi yang kita kenal hari ini, meskipun idealnya Alquran tidaklah dapat disebut sebagai sebuah karya puisi. Lebih dalam sastrawan berkebangsaan Mesir Thaha Husein berkata, bahwa setidaknya sebuah ucapan bisa diklasifikasi kepada dua, yaitu prosa dan puisi. Sedangkan Alquran tidaklah berada dalam dua klasifikasi tersebut. Artinya, Alquran berada pada posisi tersendiri yang tidak dapat disamakan dengan perkataan dan ucapan lain. Dengan kata lain,

${ }^{7}$ Surahman Amin, “Al-Qur’an Berwajah Puisi Telaah Atas Al-Qur'an Bacaan Mulia Karya H.B Jassin", Jurnal Kawistara, Vol. 6, No. 3, 22 Desember 2016, 231-232. Lihat juga https://artikula.id/muhammadrafi19/al-quran-berwajah-puisi-dan-al-quran-bacaan-mulia-h-bjassin/ (Diakses, Tanggal 04 Februari 2020). 
Alquran tidak berada dalam sebuah aturan tertentu, tetapi kalimat-kalimat dan ucapan lainlah menjadinya sebagai patron dalam pembentukan gramatikalnya. ${ }^{8}$

Menyikapi HB. Jassin dan karyanya itu, para cendekiawan di Indonesia memberikan pendapat bahwa bila ditinjau dalam aspek ilmu bahasa, Jassin telah mampu mengekspresikan terjemahan Alquran dengan nuansa yang tinggi, meskipun pada dasarnya ia bukanlah seorang pakar dalam bahasa Arab. Akibat dari ketidakpakarannya dalam bahasa Arab, para pakar tafsir pun berkesimpulan akhir bahwa Jassin tidaklah relevan menulis sebuah karya terjemah Alquran, terlebih inspirasi tersebut ditulisnya dalam bentuk puisi. Jika melihat pula pada khazanah perkembangan Tafsir di dunia, maka ditemukan pula Sayyid Quthb, ia seorang kritikus sastra dari Mesir menulis kitab tafsir berjudul Tafsīr fì Zilāl Al-Qur'ān. Dalam tafsir ini didominasi oleh kecenderungan sastra dalam menafsirkan ayat-ayat Alquran dengan keindahan bahasanya. Bahkan tidak dapat dielakkan pula ketika karya tersebut diterjemahkan ditemukan pula nilai sastra yang indah ketika dibacakan. Sebelum Sayyid Quthb juga ditemukan tafsir-tafsir yang berusaha menginterpretasi Alquran dengan menggunakan nilai-nilai sastra. Misalnya, Tafsīr Ibn Arabī, Tafsīr al-Ma'ānī dan beberapa tafsir yang bernuansa keindahan bahasa Alquran. ${ }^{9}$

Surahman Amin dalam artikelnya berjudul “Al-Qur'an Berwajah Puisi Telaah Atas Al-Qur'an Bacaan Mulia Karya H.B Jassin” berkomentar bahwa meskipun karya HB. Jassin Al-Qur'an Al-Karim dan Bacaan Mulia adalah sebuah karya yang tidak luput dari pro dan kontra dengan penulisan terjemahan Alquran dalam gaya puisi. Namun tidak dapat ditepis pula bahwa torehan ini adalah sebuah karya yang menarik ketika dibaca. Karena Jassin seorang sastrawan maka penulisannya pun penuh jiwa sastra dan begitu menjiwai ketika ia menerjemahkan tersebut. Maka tidak

${ }^{8}$ Islah Gusmian, “Kontroversi Mushaf Al-Qur'an Berwajah Puisi Karya HB. Jassin: Studi tentang Tatacara Penulisan dan Layout Mushaf Al-Qur'an”, dalam Jurnal al-Itqan, Vol. 1, No.1, Februari-Juli 2015, 44. Wawancara dengan Yusni Saby, Tanggal 21 Oktober 2019, di Program Pascasarjana Univeristas Islam Negeri Ar-Raniry Banda Aceh. Wawancara juga dengan Samsul Bahri, Tanggal 01 Oktober 2019 di Fakultas Ushuluddin dan Filsafat Universitas Islam Negeri Ar-Raniry Banda Aceh.

${ }^{9}$ Surahman Amin, “Al-Qur'an Berwajah Puisi Telaah Atas Al-Qur'an Bacaan Mulia Karya HB Jassin”, Jurnal Kawistara, Vol. 6, No. 3, $22 \quad$ Desember 2016, 232. https://artikula.id/muhammadrafi19/al-quran-berwajah-puisi-dan-al-quran-bacaan-mulia-h-bjassin/ (Diakses, Tanggal 04 Februari 2020). 
mengherankan bahwa ketika karya tersebut dibaca bisa menyentuh relung jiwa bagi siapa saja yang membacanya. ${ }^{10}$

Bagi mereka yang setuju dengan karya tersebut beranggapan bahwa karya tersebut adalah sebuah hal harus diapresiasi, sekalipun masih banyak ada kekurangan yang harus ditinjau kembali dan perlu ada perbaikan yang harus dilakukan oleh para pakar. apresiasi mereka itu sungguh pula sangat beralasan, yaitu bahwa belum ada satu orang pun yang dapat menerjemahkan Alquran secara akuratistik dalam bentuk prosa dan puitis sebagaimana HB. Jasssin, tetapi yang ada hanyalah sebuah pemahaman penerjemah terhadap teks. Namun bagi mereka yang menolak secara tegas dengan memberikan alasan yang juga konkret, bahwa Jassin bukanlah orang yang layak dalam arti tidak memiliki kapasitas untuk melakukan hal tersebut. Meskipun di sisi lain mereka setuju bahwa Jassin bermaksud untuk menyampaikan dialektika keindahan bahasa Indonesia. Namun bukan berarti menjadikan Alquran sebagai ladang sastra tanpa dasar ilmu pengetahuan dalam bidang tersebut. ${ }^{11}$ Penolakan secara umum yang dilakukan oleh berbagai kalangan yang paling menonjol adalah disebabkan oleh latar belakang keilmuan yang kurang kompeten dalam bidang Alquran. Bahkan bila dilihat secara lebih profesional, Jassin hampir-hampir tidak menguasai disiplin ilmu keagamaan lainnya. Karena menurut para penolak tersebut, bahwa mengerjakan sebuah karya terjemah Alquran harus mereka yang telah mumpuni dari semua sisi disiplin ilmu agama, paling tidak menguasai ilmu bahasa Arab dan segala gramatikal yang ada di dalamnya dan juga mengetahui kaidah bahasa sasaran yang hendak diterjemahkan agar tidak ditemukan pengkhianatan terhadap teks yang hendak diterjemahkan itu. ${ }^{12}$

Penolakan terhadap karya Jassin secara historis dan secara terstruktur juga datang dari MUI dan Departemen Agama Republik Indonesia. Hal itu sebagaimana tercantum dalam Keputusan Surat pada No. U 1061/MUI/XII/1992. Tidak sampai di situ saja, kritikan dan bahkan penolakan juga ditujukan oleh Departemen Agama melalui Lajnah Pentashih Mushaf Alquran yang ditandatangani oleh Ketua Badan

\footnotetext{
${ }^{10}$ Surahman Amin, “Al-Qur'an Berwajah Puisi Telaah Atas Al-Qur'an Bacaan Mulia Karya H.B Jassin”, Jurnal Kawistara, Vol. 6, No. 3, 22 Desember 2016, 232. https://artikula.id/muhammadrafi19/al-quran-berwajah-puisi-dan-al-quran-bacaan-mulia-h-bjassin/ (Diakses, Tanggal 04 Februari 2020).

${ }^{11}$ Bilmauidhah, "Puitisasi Terjemahan Al-Qur'an: Studi Analisis Terjemah Bersajak Bahasa Aceh", 37.

${ }^{12}$ Surahman Amin, "Al-Qur'an Berwajah Puisi Telaah Atas Al-Qur'an Bacaan Mulia Karya H.B Jassin”, Jurnal Kawistara, Vol. 6, No. 3, 22 Desember 2016, 232.
} 
Penelitian dan Pengembangan (Litbang), yaitu Lajnah Pentashih Alquran. Karena itu terbitlah Surat Keputusan No. P III/TL.02/1/242/1179/1992. Setalah dikeluarkannya surat tersebut, maka dihantarkan kepada Jassin pada awal tahun 1993 setelah karya tersebut telah dicetak sebanyak tiga kali. ${ }^{13}$

Majelis Ulama Indonesia Ulama pula harus turun tangan untuk menjelaskan serta Jassin dimintakan untuk mengklarifikasi kepada para ulama dan masuk ke sejumlah pesantren seputar terbitnya Al-Qur'an Al-Karim Bacaan Mulia itu. Betapa tidak, karena akibat dari kontroversinya karya tersebut semua media dan surat kabar nasional bahkan lokal dimunculkan beberapa saat. Pada dasarnya MUI berpendapat bahwa karya tersebut tidak menjadi sebuah hal yang fatal, karena telah diuji dan diaudit oleh para ahli ilmu Alquran di MUI yang tertuang dalam Surat tanda tashih dari Lajnah Pentashih Alquran No. I-III/198/B-II/77. Namun perlu digarisbawahi bahwa karya tersebut harus dipertimbangkan dari segi kelayakan untuk sebuah terjemahan Alquran yang bersifat sastra. Karena yang menjadi persoalan paling sentral adalah bagaimana mencari cara yang paling tepat untuk menjelaskan posisi sastra Alquran ke dalam bahasa lain. ${ }^{14}$ Bahkan Hasan Basri sebagai ketua Majelis Ulama Indonesia ketika itu mengeluarkan sebuah pernyataan dengan sebuah tudingan bahwa Jassin sedang mempermainkan Alquran sebagai landasan dalam kehidupan untuk mencapai tujuan awal penciptaan manusia di alam jagat raya ini. ${ }^{15}$ Sedangkan Menteri Agama yang menjabat pada waktu itu adalah Munawir Syazali yang secara tegas tidak merestui untuk dilakukan terhadap karya tersebut. ${ }^{16}$

Hamka -yang telah mengenal Jassin-, menurutnya bahwa Jassin adalah seorang pribadi yang sangat tulus dan memiliki kegigihan dalam hal penerjemahan Alquran berbasis puisi ini. ${ }^{17}$ Karena itu Hamka pun memberikan sebuah komentar terhadap karya Jassin dengan bijak, "Karya HB. Jassin adalah sebuah karya yang begitu luar biasa untuk dibaca, sang penulis begitu tulus dan ikhlas dalam menuangkan arti Alquran dalam bait-bait puisi. Ia meramunya dengan sastra yang indah karena renungannya

${ }^{13}$ HB. Jassin, Kontroversi Al-Qur'an Berwajah Puisi, (Jakarta: Pustaka Utama Grafiti, 1995), $17-18$.

${ }^{14}$ HB. Jassin, Kontroversi Al-Qur'an Berwajah Puisi, 17-18.

${ }^{15}$ Surahman Amin, “Al-Qur'an Berwajah Puisi Telaah Atas Al-Qur'an Bacaan Mulia Karya H.B Jassin”, Jurnal Kawistara, Vol. 6, No. 3, 22 Desember 2016, 232.

${ }^{16}$ Surahman Amin, “Al-Qur'an Berwajah Puisi Telaah Atas Al-Qur'an Bacaan Mulia Karya HB Jassin”, Jurnal Kawistara, Vol. 6, No. 3, 22 Desember 2016, 232.

${ }^{17}$ HB. Jassin, Al-Qur'an Bacaan Mulia, xv 
terhadap Alquran. Penulisan ini pun tidak dari keinginannnya untuk berbakti kepada agama agar meskipun dengan segala keterbatasan yang ia miliki." 18

Usaha penerjemahan Alquran secara puitis tidak saja terhenti pada Jassin dan beberapa tokoh lainya yang telah penulis sebutkan di atas. Tetapi pada tahun 1953 hal tersebut menjadi inspirasi bagi Mahjiddin Jusuf untuk melakukan hal serupa dengan merujuk kepada Jassin sebagai referensi pembanding. Karya Mahjiddin Jusuf ini menjadi sebuah karya dengan gaya bahasa yang tergolong unik dengan ciri khasnya sendiri. Bahasa Aceh menjadi bahasa yang digunakan dalam penerjemahannya dengan tujuan dan maksud agar Alquran dapat dipahami oleh masyarakat Aceh dengan bahasa mereka sendiri dan dengan budaya Aceh yang masyarakatnya pula suka dengan baitbait syair. Dan yang paling mengesankan bahwa karya ini malah mendapat apresiasi dari Menteri Agama pada waktu itu menjadi adalah Tarmidzi Taheer.

\section{Ulama Aceh}

Kajian tentang ulama dan ke-Acehan memang begitu menarik dibahas, karena berbicara tentang tentang Aceh adalah bicara lingkaran syariat Islam yang begitu kental. Ada sebuah kajian menarik yang dilakukan oleh Taufik Abdullah dalam bukunya Agama dan Perubahan Sosial. Salah satu bagiannya adalah mengupas terkait dengan peran ulama di daerah Aceh dan Sulawesi Selatan. Dalam konteks Aceh, ia menguraikan secara lebih mendalam bagaimana kesungguhan ulama Aceh, yang dalam realitasnya berada di luar struktur kekuasaan, tetapi selalu maju ke depan sebagai pemimpin rakyat ketika melawan penjajah Kolonial Belanda dan berhadapan dengan para uluh balang (ulee balang) yang memihak kepada Belanda. ${ }^{19}$ Begitu pula dengan peran lembaga pendidikan yang disebut dengan dayah sebagai institusi yang menghasilkan banyak ulama dalam mengembangkan nilai-nilai Islam. ${ }^{20}$

Penulis menemukan agaknya ada tiga model klasifikasi ulama yang ada di lingkungan masyarakat Aceh yang menjadi rujukan dan paduan mereka dalam segala persoalan kehidupan, terutama yang menyangkut dengan persoalan keagamaan. Klasifikasi tersebut bisa penulis uraikan adalah, yaitu Ulama Dayah, Ulama Kampus,

18 Https://artikula.id/muhammadrafi19/al-quran-berwajah-puisi-dan-al-quran-bacaan-mulia-h-bjassin/. (Diakses pada Tanggal 04 Februari 2020)

${ }^{19}$ Taufik Abdullah, dkk, Agama dan Perubahan Sosial, (Jakarta: CV. Rajawali, 1983). 21-35.

${ }^{20}$ Taufik Abdullah, dkk, Agama dan Perubahan Sosial, 21-35. 
dan Ulama Pemerintah (MPU). Perlu pula penulis garis bawah bahwa dalam Majelis Permusyawaratan Ulama (MPU) ${ }^{21}$ Aceh, para anggotanya diisi oleh perpaduan antara ulama Dayah dan ulama Kampus. Tetapi dari kalangan ulama Dayah juga banyak yang tidak mau masuk dalam struktural tersebut. Karena mereka beranggapan bahwa masuk dalam pemerintahan sama saja seperti telah mengotori diri dengan perkara syubhat, meskipun mereka mendukung para ulama Dayah yang lain masuk dalam struktural tersebut. Dalam penelitian ini, penulis memformulasikan tiga katagori tipologi ulama berdasarkan data-data dalam analisis data pada poin pembahasan di bawah dengan rincian respons-respons secara kritis.

\section{Analisis Respon Ulama Aceh Terhadap Al-Qur'an Al-Karim dan Terjemahan Bebas Bersajak dalam Bahasa Aceh}

\section{Persamaan Bunyi dan Irama}

Sebuah puisi akan dianggap indah jika memiliki bunyi dan pantulan yang indah baik ketika ia dibaca dan juga ketika ditulis dengan bait-bait yang indah. Karena itu, ada sementara pakar memberikan definisi bunyi sebagai segala sesuatu yang memberikan pantulan ritma dan juga rima. Secara lebih dalam rima diartikan sebagai sebuah pengulangan konteks bunyi dalam dunia puisi. Menguatkan hal tersebut, Marjorie Boultan sebagai dikutip oleh Herman J. Waluyo dalam bukunya Teori dan Apresiasi

${ }^{21}$ Majelis Permusyawaratan Ulama Aceh atau disingkat dengan MPU (MUI di tingkat Nasional dan Provinisi lain) adalah sebuah lembaga Independen di Provinsi Aceh terbentuk pada tanggal 3 Desember 2001 M (17 Ramadhan 1442 H) dengan lembaga mitranya adalah lembaga sejajar, yaitu DPRA dan juga Pemerintah Aceh. Pembentukan Majelis Permusyawaratan Ulama Aceh ini menjadi kuat dengan lahirnya Undang-Undang Nomor 11 Tahun 2006 terkait dengan Pemerintahan Aceh dan juga Qanun Nomor 2 Tahun 2009. Dalam hal ini, Majelis Permusyaratan Ulama menjadi mitra dengan Pemerintah Aceh dalam hal pembangunan terkhusus dalam bidang pengembangan dan penegakan syariat Islam. Kedudukan Majelis Permusyawaratan Ulama Aceh sama dengan kedudukan Majelis Ulama Indonesia baik di tingkat pusat maupun di tingkat provinsi lainnya. Perbedaan nama dengan provinsi lain karena terdapat keisimewaan yang diberikan keada Pronsi Aceh dengan lahirnya Undang-Undang Nomor 44 Tahun 1999 terkait Keistimewaan Aceh. Rincian Undang-Undang tersebut tertuang dalam pasal 9 ayat 1 bahwa "Daerah dapat membentuk sebuah badan yang anggotanya terdiri dari Ulama". Pada ayat 2 lebih tegas disebutkan bahwa "Badan yang disebutkan dalam ayat 1 adalah sebuah badan yang sifatnya independen yang berfungsi sebagai lembaga dalam rangka memberikan pertimbangan dalam berbagai kebijakan daerah yang meliputi pembangunan, pemerintahan, ekonomi dan kemasyarakatan demi terwujudnya daerah yang Islami." Dari amanat Undang-Undang tersebut tertindaklanjut dengan lahirnya Peraturan Daerah dalam Nomor 3 Tahun 2000 terkait Pembentukan Organisasi dan Tata Kerja Majelis Permusyawaratan Ulama Provinsi Nanggroe Aceh Darussalam dan Peraturan Daerah Propinsi Daerah Istimewa Aceh Nomor 43 Tahun 2001 tentang Perubahan Pertama atas Peraturan Daerah Propinsi Daerah Istimewa Aceh Nomor 3 Tahun 2000 tentang Pembentukan Organisasi dan Tatakerja Majelis Permusywaratan Ulama Propinsi Daerah Istimewa Aceh. Lihat https://mpu.acehprov.go.id/index.php/page/1/profil. Diakses pada tanggal 12 Desember 2019. 
Puisi mengatakan bahwa rima disebut juga dengan phonetic form yang dalam arti luas bahwa jika phonetic form tersebut dipadukan dengan rima maka akan menjadi sebuah puisi lebih tegas dan memiliki kandungan makna yang lebih dalam. ${ }^{22}$ Karena itu, konteks rima dalam dunia puisi akan membahas pula ruang lingkup simbol bunyi, lambang rasa, orkestrasi bunyi, dan juga kiasan dari sebuah suara yang sedang dibacakan. Lain lagi dengan ritma, ia memiliki konteks dengan sebuah frasa kata dan juga kalimat dan juga dalam hal pengulangan bunyi dari sebuah pantulan bacaan puisi.

Mahjiddin Jusuf dalam menerjemahkan Alquran telah menempuh metode sebagaimana disebutkan dalam teori persamaan bunyi di atas. Hal itu dapat dilihat dalam surah al-Fātihah yang terdapat dalam surah al-Fātiḥah ayat 1 dan 2:

Ngon nama Allah lon puphon surat

Tuhan Hadharat nyang Maha Murah

Tuhanku sidroe geunaseh that-that

Donya akhreat rahmat Neulimpah

Sigala pujo bandum lat-batat

Bandum nyan meuhat milik Potallah

Nyan peujeut alam timu ngen barat

Bandum lat-batat peuneujeut Allah. ${ }^{23}$

Jika diterjemahakan dalam bahasa Indonesia maka akan mengandung arti sebagai berikut:

Dengan nama Allah ku mulai surat

Tuhan Hadharat yang Maha Pemurah

Tuhanku Esa Maha Pengasih

Dunia akhirat rahmat berlimpah

Segala puji seru sekalian alam

Semua itu adalah milik Allah

Yang Menciptakan alam Timur dan Barat

Semua isinya ciptaan Allah

Bandingkan dengan terjemahan Kementerian Agama Republik Indonesia sebagai berikut;

\footnotetext{
${ }^{22}$ Herman J. Waluyo, Teori dan Apresiasi Puisi, (Jakarta: Erlangga, 1991), 90.

${ }^{23}$ Mahjiddin Jusuf, Al-Qur'an Al-Karim dan Terjemahan Bebas Bersajak dalam Bahasa Aceh, (Banda Aceh: Pusat penelitian dan Pengkajian Kebudayaan Islam (P3KI) Aceh, 2007), 1.
} 
Dengan menyebut nama Allah yang Maha Pemurah lagi Maha Penyayang. Segala puji bagi Allah, Tuhan semesta alam. (QS. Al-Fātiḥah: 1-2)

Dalam konteks ini, Hisyami Yazid ${ }^{24}$ memberi komentar bahwa terjemahan dalam ayat ini memang telah cukup mewakili secara pemahaman dan penafsiran secara lebih luas. Tetapi perlu ditekankan bahwa pada baris kedua dalam terjemahan tersebut agak berlebihan jika diterjemahkan dengan Tuhan Hadharat. Karena memang secara tekstual kalimat bismillah terkandung terjemah yang menunjuki kepada arti tersebut. ${ }^{25}$ Menurutnya lagi, bahwa meskipun dalam diri kalimat bismillāh tekandung takdir abtadi'u, tetapi tidak serta merta diberikan tambahan terjemahan lon peuphon surat, karena akan memberikan makna dan pemahaman yang keliru dan mengambang bagi mereka yang hendak membacanya secara pemahaman literlek. ${ }^{26}$ Kemudian ia juga menambahkan bahwa seyogyanya jika ada penambahan-penambahan dalam isi teks secara puiis maka oleh penulis atau tim penyunting hendaknya memberikan keterangan atau catatan lebih agar tidak ada silang pemahaman dalam membaca teks tersebut. ${ }^{27}$

Komentar tersebut sejalan dengan apa yang disebutkan oleh Fauzi Shaleh, bahwa menurutnya hal tersebut memang patut diberikan apresiasi terhadap usaha yang telah dilakukan oleh Mahjiddin. Tetapi perlu digarisbawahi bahwa meskipun demikian karya tersebut adalah sebuah karya hasil tangan manusia yang tentu tidak luput dari kekurangan. ${ }^{28}$ Menurutnya, dalam ayat ini haruslah diberikan beberapa catatan agar tidak terjadi kesalahpahaman dalam mengartikan arti ayat Alquran. Sebab jika tidak diberikan penjelasan lebih lanjut maka dikhawatirkan akan terjadi penambahan makna

${ }^{24}$ Hisyami Yazid adalah Dosen pada prodi Ilmu Al-Qur'an dan Tafsir, Fakultas Ushuluddin dan Filsafat Universitas Islam Negeri Ar-Raniry Banda Aceh. Pernah mengeyam pendidikan di Dayah Aceh dan kemudian melanjutkan pendidikannya di Universitas Al-Azhar Mesir. Setalah menamatkan pendidikannya di Universitas Islam itu, ia melanjutkan kembali pendidikannya pada Program Pascasarjana Universitas Islam Negeri Ar-Raniry Banda Aceh. Setalah menamatkan Program Magisternya, ia melanjutkan kembali pada program Doktor di Sekolah Pascasarjana Universitas Islam Negeri Syarif Hidayatullah Jakarta. Dan sekarang ia aktif mengajar dan aktif pula pada Majelis Permusyawaratan Ulama Kota Banda Aceh. Banda Aceh.

${ }^{25}$ Wawancara dengan Hisyami Yazid, tanggal 03 Oktober 2019, di kediaman Jeulingke, Kota

${ }^{26}$ Wawancara dengan Hisyami Yazid, tanggal 03 Oktober 2019, di kediaman Jeulingke, Kota Banda Aceh.

${ }^{27}$ Wawancara dengan Hisyami Yazid, tanggal 03 Oktober 2019, di kediaman Jeulingke, Kota Banda Aceh.

${ }^{28}$ Wawancara dengan Fauzi Shaleh, tanggal 02 Oktober 2019, di Universitas Islam Negeri ArRaniry, Banda Aceh. 
Alquran yang berujung kepada $t a h\} r i f^{29}$ Alquran. Jika hal tersebut dibiarkan maka akan ditakutkan berimbas pada aspek teologis umat Islam secara umum dan masyarakat Aceh secara khusus. ${ }^{30}$

Demikian pula komentar yang diberikan oleh Muhammad Yusuf A. Wahab ${ }^{31}$, bahwa haruslah sangat berhati-hati dalam upaya menerjemahkan Alquran. Sebab Alquran adalah kitab suci umat Islam yang sangat sakral sebagai pedoman dalam setiap kehidupan. Jika ayat-ayat tersebut diterjemahkan tanpa mengikuti kaidah-kaidah yang telah ditetapkan oleh para ulama yang muktabar maka sangat dikhawatirkan terjatuh dalam kekeliruan yang menyebabkan terdistorsinya kandungan Alquran sebagaimana yang diinginkan. Boleh saja menerjemahkan Alquran dengan menyesuaikan bunyi dan sajak, tetapi harus menjadi perhatian pula bahwa jangan karena hendak mengindahkan bunyi dan rima akhir tetapi mengabaikan kaidah yang ada, sehingga arti yang seharusnya ditimbulkan dalam terjemahan harus terhilangkan karena aspek-apek yang mengharuskan penyesuaian puisi. ${ }^{32}$

Faisal $\mathrm{Ali}^{33}$ sebagai Wakil ketua Majelis Permusyawaratan Ulama (MPU) Aceh juga memberikan komentar menarik yang berbeda dengan Muhammaad Yusuf A. Wahab dan juga beberapa ulama lainnya. Menurutnya karya Mahjiddin tersebut adalah sebuah gambaran bahwa bahasa Aceh juga mampu menjadi sebuah bahasa yang mampu mentransformasi nilai-nilai keagamaan baik yang berasal Alquran sebagai sumber utama dalam ajaran Islam. Lebih spesifik ia mengatakan bahwa tidaklah mengapa menerjemahkan Alquran dalam bentuk puisi dengan menyesuaikan bait-bait akhir

${ }^{29}$ Dalam Lisān al-Arab, Ibn al-Manzūr mengatakan bahwa yang dimaksud dengan tahrif adalah perubahan baik dalam hal huruf maupun makna yang dikandung atau sesutu yang berdekatan dengannya. Hal itu sebagaimana yang dilakukan oleh Yahudi dalam rangka merubah ayat dan makna Taurat dengan makna yang serupa namun tidak sama. Demikian halnya dalam al-Mufradāt fí Gharīb Al-Qur'ān, Raghib al-Asfahani menulis bahwa tahriff adalah pengalihan sebuah makna kepada makna yang lain yang mengakibatkan maknanya terdistorsi secara lebih jauh bahkan berkali lipat maknanya berubah. Lihat Ibn Manzūr, Lisān al-Arab, cet. ke 3, jilid 9 (Beirūt: Dār as-Șadir, 1994), 42. Lihat juga, Rāghib al-Asfāhānī, al-Mufradāt fì Gharīb Al-Qur'ān, (Beirüt: Dār al-Ma'rifah, tt), 114. Lihat juga, M. Nur Kholis Setiawan, 'Book Review: Syi'ah dan Wacana Perubahan Al-Qur'an, Tahrif Al-Qur'an, dalam Jurnal Al-Jami'ah, Vol. 43, No. 1, 2005/1426 H.

${ }^{30}$ Wawancara dengan Fauzi Shaleh, tanggal 02 Oktober 2019, di Universitas Islam Negeri ArRaniry, Banda Aceh.

31 Muhammad Yusuf A Wahab adalah pimpinan Dayah Babussalam Al-Aziziyah Jeunib, Kabupaten Bireuen, Provinsi Aceh. Ketua Himpunan Ulama Dayah Aceh (HUDA) dan ketua Barisan Muda Umat (BMU) yang bergerak dalam bidang sosial kemasyarakatan.

${ }^{32}$ Wawancara dengan Muhammad Yusuf A. Wahab, tanggal 15 Oktober 2019, di kediaman Lambhuk, Kota Banda Aceh.

${ }^{33}$ Faisal Ali adalah Pimpinan Dayah Mahyal Ulum A-Aziziyah, Sibreh, Kabupaten Aceh Besar, Provinsi Aceh. Menjabat sebagai wakil ketua Majelis Permusyawaratan Ulama (MPU) Provinsi Aceh. 
dalam bentuk sajak $a b a b$. Terlebih jika melihat karya Mahjiddin di mana di dalamnya tidak mengandung distorsi-distorsi terhadap ayat-ayat Alquran itu sendiri. Bahkan lebih dalam Mahjiddin Jusuf telah mampu menyalurkan substansi Alquran dengan baik dalam pendetakan budaya orang Aceh. ${ }^{34}$ Alyasa' Abubakar ${ }^{35}$ pun memberikan respon baik terhadap terjemahan ayat ini. Menurutnya terjemahan ayat terkait sumpah sudah memenuhi kriteria dalam kaidah-kaidah terjemahan dan sudah sesuai sebagaimana yang ditetapkan oleh para ulama-ulama terdahulu. Meskipun dilain sisi dalam aspek terjemahan yang lain masih terdapat beberapa tempat yang mesti dikaji ulang dan bahkan bisa dikaji oleh mereka yang menggeluti bidang ilmu Alquran. ${ }^{36}$

\section{Fawātih al-Suwar (Ayat Muqațta'ah)}

Ibn Ab̄i al-Ișba' dalam karyanya $B \bar{a} d \bar{\imath}$ 'Al-Qur'ān membahas dan mengkaji secara khusus dalam satu bab berjudul al-Khawāhir al-Sawānih fì Asrār al-Fawātih. Begitu pula dengan al-Suyūṭi dalam al-Itqān fì Ulūm Al-Qur'ān menjelaskan persoalan tersebut dengan memberi dalam satu bab berjudul Awāil al-suwār. ${ }^{37}$ Huruf fawātih alsuwār atau disebut juga dengan huruf munqat\}a'ah yang terdapat pada awal surat oleh para ulama tidak memberikan sebuah terjemahan kepada huruf tersebut, melainkan hanya menerjemahkannya berdasarkan bunyi yang ada pada huruf tersebut. Seperti alif lām mìm, alif lām rāa, alif lām mìm șâd dan lain-lain yang bisa didapatkan dalam beberapa surat dalam Alquran. Karena sebab tidak diterjemahkan ayat dan huruf tersebut, maka para ulama pun mengklasifikasikannya dalam ayat-ayat mutasyābihāt. ${ }^{38}$

\footnotetext{
${ }^{34}$ Wawancara dengan Faisal Ali (Wakil Ketua Majelis Permusyawaratan Ulama Aceh), tanggal 14 Januari 2020 di hotel Blue Sky Jakarta Pusat.

${ }^{35}$ Professor dan guru besar dalam bidang Ushul Fiqih pada Universitas Islam Negeri Ar-Raniry Banda Aceh.

${ }^{36}$ Wawancara dengan Alyasa' Abubakar, pada tanggal 22 Oktober 2019 di Fakultas Hukum dan Syariah Universitas Islam Negeri Ar-Raniry Banda Aceh.

37 Jalāl al-Dīn al-Suyūṭi, Al-Itqān fì 'Ulūm Al-Qur'ān, Juz II, (Kairo: Al-Maktabah alTaufĩqiyyah, tt.), 12, 43 dan juga lihat al-Itqān Juz II dalam bab al-Ayāt al-Mutasyābihät, 133.

38 Dalam Al-Qur'an terdapat beberapa ayat secara garis besar yang digolongkan dalam ayat mutasyabihat, seperti ayat tentang sifat dan keberadaan Allah, huruf pada permulaan surat, tanda kiamat dan hakikat hari akhir. Terjadi perbedaan pendapat di kalangan para ulama terkait ayat mutasyabihat dan mmuhkamat, terutama ketika memaknai QS. Ali 'Imran: 7. Namun begitu, ada sebuah definisi yang banyak ulama bersepakat bahwa muhkamat adalah ayat Al-Qur'an yang sudah diketahui penafsirannya secara jelas. Sedangkan ayat mutsyabihat adalah ayat Al-Qur'an yang penafsiranya belum ketahui secara jelas dalam semua sisi, kecuali hanya Allah saja yang mengetahuinya. Lihat, Mannā' KhaГil al-Qattāan, Mabāhis fì 'Ulüm Al-Qur'ān, 207.
} 
Adapun dalam aplikasi yang dilakukan oleh Mahjiddin dalam proses menerjemahkan huruf-huruf potong tersebut ia hanya memberikan penjelasan dan pemberitahuan sebagai berikut:

\section{Tuhan nyang teupue meukeusud ayat}

\section{Sabab Hadharat hana Neupeugah}

Artinya:

Tuhan yang mengetahui maksud ayat

Sebab Hadharat tidak mengatakannya

Yusni Saby memberikan komentar terkait penerjemahan tersebut bahwa Mahjiddin telah menempuh jalur metode sebagaimana dilakukan oleh para ulama terdahulu ketika berhadapan dengan ayat-ayat mutasyābihāt. Menurutnya, bahwa memang sejatinya ayat tersebut tidak dapat ditafsirkan secara panjang lebar dengan segala keterbatasan yang diberikan Allah Swt kepada manusia. Dalam kesempatan yang sama Allah pula ingin menunjukkan kepada manusia akan keterbatasan mereka dan menampakkan bahwa Ia Maha Mengetahui segala sesuatu dengan tidak serta merta memahami Alquran sesuka manusia, meskipun Alquran ditulis dalam bahasa Arab sebagai sebuah alat komunikasi orang Arab. Namun harus digarisbawahi bahwa bahasa Alquran sungguh berbeda dengan bahasa Arab dalam semua sudut pandang. ${ }^{39}$

Yusni Saby memang menjadi bagian Majelis Permusyawaratan Ulama (MPU) Aceh. Tetapi ia juga sekaligus menjadi bagian dari akademisi kampus yang berlatar belakang ilmu sejarah dan berpendidikan di Barat pada McGill University Canada, Amerika Serikat. Dilihat dari basik pendidikan memang ia adalah seorang modernis. Sikapnya terhadap karya Mahjiddin adalah sangat baik dan mendapatkan apresiasi yang sangat baik darinya, dan bahkan ia menjadi bagian dari Tim Penyunting kedua dari karya tersebut.

Begitu pula komentar Muhammad Yusuf A. Wahab, bahwa menurutnya hal ini sudah sesuai dengan kaidah-kaidah yang digagas oleh para ulama tafsir baik dari masa dahulu hingga sekarang. Begitu pula sudah sesuai dengan kaidah-kaidah Alquran dan juga hadis sebagai ajaran pokok dari umat Islam yang sangat konsisten menjaga keautentikannya sendiri dengan segala pengakuan yang ada di dalamnya. Hal itu tentu berbeda dengan kitab-kitab samawi lainnya yang keautentikannya tidak bisa

39 Wawancara dengan Yusni Saby, tanggal 21 Oktober 2019, di Program Pascasarjana Universitas Islam Negeri Ar-Raniry Banda Aceh. 
dipertahankan sama sekali. Begitu pula dengan kitab agama lain yang segala isinya telah banyak sekali mengandung distorsi dan campur tangan manusia, sehingga memberikan ruang kotor kemurnian agama. ${ }^{40}$ Bahkan dari segi akurasi terjemahannya juga perlu ditinjau ulang agar tidak terjadi missing maksud Alquran baik secara tekstural maupun secara kontekstual.

\section{Kesimpulan}

Dari respon ulama Aceh terhadap Al-Qur'an Al-Karim dan Terjemahan Bebas Bersajak dalam bahasa Aceh maka penulis menemukan kesimpulan dengan ragam macam respon dengan sampel yang dijadikan pembatasan meliputi; penyamaan bunyi dan irama, tafsir dan perluasan makna, pendekatan sosial-budaya, terjemah ayat antropomorfisme (ayat mutasyabīhāt), dan fawātih̆ al-Suwār. Dari 12 responden yang penulis wawancara, 9 responden yang mengambil sikap bahwa pendekatan budaya dalam terjemahan karya tersebut harus dikaji ulang.

Pada indikator lain, seperti fawātih al-Suwār, ayat-ayat mutasyābihāt, masukan terhadap penerjemahan tersebut hampir sama dengan indikasi di atas. Secara konten dalam konteks ayat mutasyābihāt para responden semua setuju dengan pendekaran terjemahan yang Mahjiddin gunakan karena sudah sesuai dengan kajian-kajian para ulama terdahulu dengan berbagai literatur yang ada. Dan setelah menganalisis dari beberapa respon ulama dari aspek bentuk terjemah maka dapat disimpulkan bahwa yang dilakukan oleh Mahjiddin Jusuf merupakan sebuah karya terjemah tafsīriyah menginterpretasi ayat Alquran dalam bentuk terjemah dan juga memberikan sedikit penjelasan yang penting agar tidak terdapat kesalahpahaman ketika dibaca.

\section{Daftar Pustaka}

Abbas, Siradjuddin, Sorotan atas Terjemahan Al-Qur'an HB. Jassin, (Jakarta: Pustaka Tarbiyah, 1979.

Abd al-Jabbār, Al-Mughnī fì Abwāb al-Tauhīd wa al-'Adl, Juz, 7, Tk: tp, tt.

Abdullah, Taufik dkk, Agama dan Perubahan Sosial, Jakarta: CV. Rajawali, 1983.

Abū Zayd, Naṣr Hamīd, Mafhūm al-Nașṣ: Dirāsāt fì 'Ulūm Al-Qur'ān, Kairo: al-Hai'ah al-Misriyyah al-Ummah li al-Kuttāb, 1993.

${ }^{40}$ Wawancara dengan Muhammad Yusuf A. Wahab, tanggal 15 Oktober 2019, di kediaman Lambhuk, Kota Banda Aceh. 
Al-'Uṡaimīn, Muhammad Ibn Sālih, Syarḥ Muqaddimah Usāl al-Tafsīr, Riyad: Dārul Minhāj, 1432 H.

Alfian, Ibrahim, "The Ulama in Acehnese Society", dalam Ahmad Ibrahim, Sharon Siddique \& Yasmin Husain (eds.) Reading on Islam in Southeast Asia, Singapore: Institute of Asian Studies, 1985.

Al-Sāliḥ, Subhī, Membahas Ilmu-Ilmu Al-Qur'an, (Bogor: Litera Antar Nusa, 1994.

Al-Sayūṭị, al-Itqān fì 'Ulūm Al-Qur'ān, Beirut: Dār al-Kutub al-Ilmiyyah, 2000.

Al-Suyūṭ̣̂, Jalāl al-Dīn, Al-Itqān fì 'Ulūm Al-Qur'ān , Juz II, Kairo: Al-Maktabah alTaufĩqiyyah, tt.

Al-Zarkashī, Muhammad Ibn Bahādir Ibn Abdullah, al-Burhān fì 'Ulūm Al-Qur'ān, Vol. 1, Bairut: Dār al-Ma'rīfah, 1391 H.

Al-Zarqānī, Muhammad 'Abd al-'Azīm, Manāhil al- 'Irfān fì 'Ulūm Al-Qur'ān, Beirūt: Dār al-Kutub al-'Ilmiyyah, 1996 M.

Amal, Taufik Adnan, Rekonstruksi Sejarah Al-Qur'an, Yogyakarta: FkBA, 2001.

Amin, Surahman, “Al-Qur'an Berwajah Puisi Telaah Atas Al-Qur'an Bacaan Mulia Karya H.B Jassin”, Jurnal Kawistara, Vol. 6, No. 3, 22 Desember 2016, 231232.

Anwar, Rosihon, Ulumul Qur'an, Bandung: CV Pustaka Setia, 2013.

Baidan, Nashruddin, Metodologi Penafsiran Al-Qur'an, Jakarta: Pustaka Pelajar, 1988.

Bakry, Oemar, Polemik H. Oemar Bakry dengan H.B. Jassin tentang Al-Qur'an AlKarim Bacaan Mulia, Jakarta: Mutiara, 1979.

Bilmauidhah, "Puitisasi Terjemahan Al-Qur'an: Studi Analisis Terjemah Al-Qur'an Bersajak Bahasa Aceh”, Tesis pada Sekolah Pascasarjana Universitas Islam Negeri Syarif Hidayatullah, Jakarta: UIN Syarif Hidayatullah, 2010.

Effendi, Edy A., “Kontroversi di Sekitar HB. Jassin”, dalam Jurnal Ulumul Qur'an, November 1993.

Ghozali, Moh. Alwy Amru, “Takwil dalam Perspektif ‘Abd Al-Jabbar: Sebuah Tawaran Hermeneutika Al-Qur'an", dalam Jurnal Ushuluddin dan Dakwah STAIN Ponorogo.

Gilani, S. M.Yunus, "Ilm, 'Ulum and the 'Ulama”, Journal Hamdard Islamicus, No. 13, Vol. 4, Tahun, 2000. 
Gusmian, Islah, “Kontroversi Mushaf Al-Qur'an Berwajah Puisi Karya HB. Jassin: Studi tentang Tatacara Penulisan dan Layout Mushaf Al-Qur'an”, dalam Jurnal al-Itqan, Vol. 1, No.1, Februari-Juli 2015.

Hassan, Ahmad, Al -Furqan: Tafsir Al-Qur'an, Jakarta: Dewan Dakwah Islamiyyah Indonesia, 1956.

Https://artikula.id/muhammadrafi19/al-quran-berwajah-puisi-dan-al-quran-bacaanmulia-h-b-jassin/ (Diakses, Tanggal 04 Februari 2020).

Https://mpu.acehprov.go.id/index.php/page/1/profil. Diakses pada tanggal 12 Desember 2019.

Ibn Kas̄īr, Tafsīr Al-Qur'ān al-Azhīm, Beirūt: Dār Ibn Hazm, 2000, 123.

Ibn Manzūr, Lisān al-Arab, cet. ke 3, jilid 9, Beirūt: Dār as-Ṣadīr, 1994. Rāghib alAsfāhānī, al-Mufradāt fì Gharīb Al-Qur'ān, Beirūt: Dār al-Ma'rīfah, tt.

Jassin, HB., Al-Qur'an Al-Karim Bacaan Mulia, Jakarta: Djambatan, 1991, cet. 3.

Jassin, HB., Kontroversi Al-Qur'an Berwajah Puisi, Jakarta: Pustaka Utama Grafiti, 1995.

Juneidi, Didi, “Living Qur'an: Sebuah Pendekatan Baru dalam Kajian Al-Qur'an, (Studi Kasus di Pondok Pesantren As-Siroj Al-Hasan Desa Kalimukti Kec. Pabedilan Kab. Cirebon)", Journal of Qur'ān and Hadis Studies - Vol. 4, No. 2, Tahun 2015.

Jusuf, Mahjiddin, Al-Qur'an Al-Karim dan Terjemahan Bebas Bersajak dalam Bahasa Aceh, Banda Aceh: Pusat penelitian dan Pengkajian Kebudayaan Islam (P3KI) Aceh, 2007.

Marshall, Gordon, "Talcott Persons”, dalam A Dictionary of Sociology, Oxford: Oxford University Press, 1998.

Masdari, "Mengindentifikasi Tipologi Ulama Pewaris Nabi”, dalam Masdari \& Zulfa Zamalie (eds.) Khazanah Intelektual Ulama Banjar, Banjarmasin: PPIK, 2003.

Maslahah, Ani Umi, “Al-Qur'an, Tafsir, dan Ta'wil Dalam Perspektif Sayyid Abu AlA'la Al-Maududi", dalam Jurnal Hermeneutik, Vol. 9, No. 1, Juni 2015.

Moesa, Ali Maschan, Nasionalisme Kiai, Konstruksi Sosial Berbasis Agama, Yogyakarta: Lkis, 2007.

Newmark, Peter, Approaches to Translation, Oxford: Pergamon Press, 1981. 
Patrick J. Dubbs dan Daniel D Whitney, Cultural Context, Making Anthropology Personal, London: Allyn \& Bacon Inc, 1938.

Ritonga, Abdul Hamid, "Hadis-Hadis Antropomorfisme: Analisis terhadap Takwi>1 Ibn Hajar al-'Asqālāni dalam Fatḥ al-Bārī’, dalam Jurnal MIQOT, Vol. XXXVII No. 2 Juli-Desember 2013.

Saeed, Abdullah, Al-Qur'an Abad 21 Tafsir Kontekstual, Bandung: Mizan, 2016.

Saleh, Ahmad Syukri, Metodologi Tafsir Al-Qur`an Kontemporer dalam pandangan Fazlur Rahman, Jakarta: Sulthan Thaha Press, 2007.

Sanaky, Hujair A. H., "Metode Tafsir: Perkembangan Metode Tafsir Mengikuti Warna atau Corak Mufassirin”, dalam Jurnal Al-Mawarid, Edisi XVIII Tahun 2008.

Setiawan, M. Nur Kholis, "Book Review: Syi'ah dan Wacana Perubahan Al-Qur'an, Tahrif Al-Qur'an, dalam Jurnal Al-Jami'ah, Vol. 43, No. 1, 2005/1426 H.

Shaleh, Fauzi, "Mengungkap Keunikan Tafsir di Aceh”, Jurnal al-Ulum, vol. 12, no. 2, Tahun 2012

Shihab, M. Quraish, Kaidah Tafsir, Tangerang: Lentera Hati, 2013.

Shihab, M. Quraish, Tafsir al-Mishbah; Pesan, Kesan dan Keserasian Al-Qur'an, vol. 7, Jakarta: Lentera Hati, 2006.

Syamsu, Nazwar, Koreksi Terjemah Al-Qur'an Al-Karim Bacaan Mulia HB. Jassin, Padang Panjang: Pustaka Sa'adiyyah, 1978.

Syamsuddin, Sahiron, (ed.), Metode Penelitian Living Qur'an dan Hadis, Yogyakarta: Teras, 2007.

TO. Ihromi (ed), Pokok-pokok Antropologi Budaya, Cet. 7, Jakarta: PT Gramedia 1994. Wāfī, Alī 'Abd al-Wāhid, al-Lughah wa al-Mujtama', Kairo: Dār Ihyā al-Kutub alArabiyyah Isa babi al Halabi wa syirkahu, 1951.

Waluyo, Herman J., Teori dan Apresiasi Puisi, Jakarta: Erlangga, 1991.

Wan The, Wan Hashim, "Perubahan Sosial: Teori-teori Klasik dan Moden", Jurnal Antropologi dan Sosiologi, No. 12, Tahun 1984.

Webster, Andraw, Introduction to the Sociology of Development, London: Macmillan Publishers Ltd., 1984.

Zaman, Iftikhar, "Sunni 'Ulama", dalam John L. Esposito (ed.) The Oxford Encyclopedia of the Islamic World, Vol. 4, New Yok \&Oxford: Oxford University Press, 1995. 
Zaman, Muhammad Qasim, The Ulama in Contemporary Islam, Custodians of Change, Princeton \& Oxford: Princeton University Press, 2002.

Wawancara dengan Alyasa' Abubakar, pada tanggal 22 Oktober 2019 di Fakultas Hukum dan Syariah Universitas Islam Negeri Ar-Raniry Banda Aceh.

Wawancara dengan Azman Ismail, tanggal 14 Oktober 2019 di Masjid Raya Baiturrahman Banda Aceh.

Wawancara dengan Faisal Ali, Wakil Ketua Majelis Permusyawaratan Ulama Aceh, tanggal 14 Januari 2020 di hotel Blue Sky Jakarta Pusat.

Wawancara dengan Fauzi Shaleh, tanggal 02 Oktober 2019, di Universitas Islam Negeri Ar-Raniry, Banda Aceh.

Wawancara dengan Hasanoel Basri HG, tanggal 08 Februari 2020, di Bandara Soekarnoe Hatta, Tangerang Selatan.

Wawancara dengan Hisyami Yazid, tanggal 03 Oktober 2019, di kediaman Jeulingke, Kota Banda Aceh.

Wawancara dengan Muhammad Yusuf A. Wahab, tanggal 15 Oktober 2019, di kediaman Lambhuk, Kota Banda Aceh.

Wawancara dengan Muntasir A. Kadir, tanggal 08 Februari 2020, di Pesantren MUDI Mekar Al-Aziziyah, Pondok Gede, Bekasi.

Wawancara dengan Nuruzzahri, tanggal 16 Oktober 2019, di Dayah Ummul Aiman Samalanga Bireun.

Wawancara dengan Samsul Bahri, tanggal 01 Oktober 2019 di Fakultas Ushuluddin dan Filsafat Universitas Islam Negeri Ar-Raniry Banda Aceh.

Wawancara dengan Yusni Saby, Tanggal 21 Oktober 2019, di Program Pascasarjana Univeristas Islam Negeri Ar-Raniry Banda Aceh. 